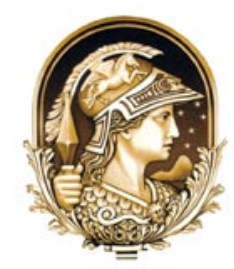

Anuário do Instituto de Geociências - UFRJ

\title{
Função das Presas Caniniformes no Dicinodonte Dinodontosaurus Romer, 1943 (Synapsida, Anomodontia)
}

Function of the caniniform tusks in the dicynodont Dinodontosaurus Romer, 1943 (Synapsida, Anomodontia)

\author{
Leonardo Morato ${ }^{1}$; Cesar Leandro Schultz ${ }^{2} \&$ Cristina Vega-Dias ${ }^{3}$ \\ ${ }^{1}$ Departamento de Geologia, Instituto de Geociências, UFRJ. Av. Brigadeiro Trompowsky, s/n, Prédio CCMN, \\ Ilha do Fundão, 21.914-900. Rio de Janeiro, RJ \\ E-mail: gepaleo@yahoo.com.br \\ ${ }_{2}^{2}$ Departamento de Paleontologia e Estratigrafia, Instituto de Geociências, UFRGS. Av. Bento Gonçalves, 9500, \\ 91.501-970, Cx. P. 15001, Porto Alegre, RS \\ ${ }^{3}$ Departamento de Geologia, UFPR. Centro Politécnico, 81.531-980, Cx. P. 19001, Curitiba, PR.
}

Recebido em: 30/03/2007 Aprovado em: 27/07/2007

As limitações mecânicas impostas pela musculatura são significativas sobre o grau de abertura da mandíbula e repercutem diretamente na forma de obtenção de alimento dos vertebrados, especialmente quando lidamos com animais com presas hipertrofiadas. Esse é o caso de Dinodontosaurus, um dicinodonte de médio porte do Mesotriássico do Rio Grande do Sul, em que as presas caniniformes se estendiam ventralmente a partir da borda das maxilas, atingindo, apenas na porção exposta do dente, cerca de um terço do comprimento total do crânio, em alguns espécimes. Em seção transversal, as presas são praticamente circulares, indicando que não há uma direção preferencial de atuação. A musculatura adutora da mandíbula, neste gênero, tinha seu ponto de inserção deslocado anteriormente, para aumentar os braços de alavanca das forças geradas pelos músculos. Este arranjo potencializava, por um lado, maior eficiência da força empregada na porção anterior da mandíbula, mas atuava, porém, em detrimento do ângulo de abertura da mesma. Observando as fibras mais posteriores da musculatura adutora, que correspondem especialmente à parte posterior do $M$. adductor mandibulae externus lateralis e ao $M$. adductor mandibulae posterior, é possível admitir uma abertura mandibular máxima formando um ângulo de cerca de $45^{\circ}$, insuficiente para permitir significativo espaço livreentreas presas e a mandíbula, do qual ainda teria que ser descontada a extensão das projeções córneas que cobriam a maxila, pré-maxila e dentário. Marcas de desgaste dentário, embora não muito nítidas, parecem ser vistas ao menos na face medial das presas, o que poderia ser creditado apenas ao atrito sofrido com a ranfoteca. Mesmo não havendo condição de Dinodontosaurus empregar as presas com a mandíbula aberta, alguns exemplares exibem algum desgaste em suas extremidades, deixando-as arredondadas. Nos indivíduos adultos, a única forma da extremidade das presas ser utilizada, independente de sua função, seria com a mandíbula elevada e retraída, de modo que as presas ultrapassassem ventralmente a borda inferior da mandíbula. Mesmo assim, devido à posição ventral das presas no crânio, o animal precisaria flexionar consideravelmente os membros anteriores ou deitarse completamente no chão para que elas pudessem alcançar o solo (para serem utilizadas em escavações do substrato, por exemplo). Uma outra possibilidade seria o emprego das presas para romper ou rasgar cascas de árvores, ou ainda para descamar algum tipo de infrutescência, mas isso poderia exigir uma elevação demasiada do crânio, com forte torção dorsal do pescoço. Entretanto, o posicionamento e a orientação do crânio em Dinodontosaurus, aliados à morfologia do côndilo occipital, com seus dois côndilos laterais incipientes, ao pescoço curto e à configuração da musculatura cervical, não indicam qualquer especialização para movimentos vigorosos de flexão da cabeça ou pescoço. Embora suas funções na alimentação sejam especulativas e, sob diversos aspectos, questionáveis, as presas, em Dinodontosaurus, certamente possuíam um papel como ornamentação. É provável que elas fossem utilizadas como um sinal visual de alerta contra predadores ou que determinassem dimorfismo sexual e hierarquias dentro do grupo. Em cenários extremos, talvez pudessem ser usadas para golpear os flancos de outros machos, em disputas por território ou por acasalamento, através de curtos golpes da cabeça. 